Article

\title{
Expert Evaluation of Subsidies for the Management of Fragmented Private Forest in Regards to National Biodiversity Goals-The Case of Kochi Prefecture, Japan
}

\author{
Dennis Gain * and Tsunemi Watanabe \\ School of Economics \& Management, Kochi University of Technology, Kochi 780-8515, Japan; \\ watanabe.tsunemi@kochi-tech.ac.jp \\ * Correspondence: dennisgain@gmail.com; Tel.: +81-80-5669-8193 \\ Academic Editor: Barry Brook \\ Received: 31 January 2017; Accepted: 12 April 2017; Published: 17 April 2017
}

\begin{abstract}
This paper presents an expert evaluation of the subsidy scheme for private forest plantations in Kami City, Kochi Prefecture, Japan, to determine whether the twelve currently available subsidies are designed to realize national biodiversity goals. Subsidies for forestry practices are often criticized for rarely achieving planned outcomes and for environmental threats. Threats to natural balance of private forest have been observed in Kochi Prefecture, suggesting that current forestry subsidies may not be achieving national objectives. The utilization objectives, type of management, requirements, area, intensity, and subsidy rates were contrasted to the three forest multifunctionality objectives of the National Biodiversity Strategy of Japan (NBSJ) 2012-2020, to identify subsidy weaknesses. Focus group discussions (FGD) were conducted in the study site, as well as Bavaria, Germany and Steiermark, Austria, to get a big picture of how experts in these comparable management areas evaluate the Kochi subsidy scheme. Analyses were performed based on a combination of framework analysis and constant comparison analysis. It was found that realization of vertical multifunctionality is hindered due to lack of site-specific management. A six-point proposal for restructuring the subsidy scheme, leaned on results, and the Bavarian subsidy scheme was made. To improve vertical multi-functionality, subsidy schemes should focus on forest owner integration and site-specific, long-term oriented forest works.
\end{abstract}

Keywords: sustainable forest management; harmful subsidies; small-scale forestry; focus group; multifunctional forestry; integrated forestry; Japan; Kochi Prefecture

\section{Introduction}

Many forest plantations are influenced by unsustainable decisions made in the past [1]. Forestry sectors in many nations are adapting policy and management instruments towards the multi-functional use of forests. However, stakeholder opinion does often not match with governmental objectives regarding sustainability goals. Ways to mitigate the unsustainable past decisions to realize local sustainability are being investigated in many nations [2]. One common driver for realizing sustainability objectives in private plantations are subsidies. Plantation subsidies are often justified for conserving multi-functional forestry (MFF), including productivity and biodiversity [3-7].

There has been a debate since the mid-20th century about how to address MFF. The "vertical" model suggests management practices for the fulfillment of two or more forest functions at a landscape scale [5], while the "horizontal" model describes patterns of multifunctionality where units of forest are dedicated to different functions [8]. This debate of forest scale and geography deals with the two key elements of MFF, (1) joint production of commodity and non-commodity forest goods and services; 
and (2) the issue that non-commodity forest goods and services include public goods [9]. Being focused on ecosystem services, more science attention can be observed for the vertical understanding of MFF, especially during the end of the 20th century. It is, however, important to note that the benefits of either MFF model are case, scale and context specific [10]. One model can be more beneficial given the circumstances, where the capabilities of actors, their preferences and beliefs are also influential [11]. Focus on vertical MFF often creates the problem that stakeholders do not always evaluate the production of non-commodity goods and services as equal in importance to the production of commodity goods. This disparity often causes a gap between policy, decisions and actual practice [12]. Therefore, subsidies may not always realize desired outputs and can affect economic development and the environment. In worst cases, the cost for mitigation must be paid by society [13-15].

Research on subsidies for plantations has identified risks for environmental side effects, such as hindrance of afforestation [16], decreasing use of natural forest [7], loss of old growth forest [17], and loss of biodiversity [3]. Complex forest structures control the risk of loss of biodiversity [18]. However, plantation subsidies can lead to on-site management practices that cause the exact opposite $[15,19]$. Such harmful subsidies are inhospitable for a sustainable development [20,21] and must be eliminated to avoid further damage to man-made and natural capital [22]. To do so, action plans are being implemented worldwide [13,23,24], such as Finland's Biodiversity Action Plan which targets the identification and reallocation of subsidies that risk damage of biodiversity [25].

\section{Forest Subsidies in Japan}

In Japan, subsidizing forest plantations is a strategy that follows two main objectives: (1) to increase man-made capital by improving the profitability of the domestic forestry industry against imported low-cost primary timber products, and (2) to enhance natural-capital by conserving vertical MFF. Given the worldwide trend towards vertical MFF, attention to the second objective has been growing. As a result, the Japan Ministry of the Environment (MOE) has adopted the new National Biodiversity Strategy of Japan (NBSJ) 2012-2020. Forest owners are recommended to develop their plantations into multi-storied mixed forests with coniferous and broad-leaved species by using the abilities of nature [26]. As research suggests, such a mixed-species strategy has the potential to improve natural capital through enhanced vitality and forest robustness, while mitigating the environmental effects of climate change $[4,10,27]$.

Approximately $58 \%$ of forestland in Japan is private forest, about $40 \%$ are plantations $[28,29]$. Approximately 2.5 million private forest owners hold forest areas of less or equal to one hectare [30]. Due to this large area of fragmented private forest, the execution of effective management has been a great challenge, mainly due to a widening gap between recent forestry trends and public wants and needs [31]. Moreover, poor profitability has led to a decrease in forestry engagement by private forest owners [32]. Forestry subsidies seldom fulfill their economic and environmental objectives [33]. Unsustainable developments raise the question as to whether current subsidy schemes are formulated and implemented to reach national objectives [34]. Therefore, research needs to be conducted to evaluate whether subsidy schemes for local private forest in Japan are designed to reach national objectives.

The purpose of this study is to analyze the current subsidy scheme for private plantations on a case, scale and context rationale in Kami City/Kochi Prefecture, Japan, to identify causes for gaps between policy and practice that hinder the realization of vertical MFF. The analysis is performed cross-national in Japan (Kochi Prefecture), Germany (Bavaria) and Austria (Steiermark) to get a big picture of how experts in these countries evaluate the applied works of the subsidy scheme and forest subsidy schemes in general. Bavaria was selected because it is an advanced forestry sector that promotes site-multifunctionality, which has similar structures of fragmented small-scale private forest and has undergone a similar development in regards to plantation management. Steiermark, in addition, was selected because it has a comparable mountain topography, which requires widespread 
use of similar logging equipment. This research is important for practitioners as basis for subsidy application, and policy makers at the national-level as foundation for decision-making processes related to future subsidization of private plantations. This research can also be of interest to those interested in plantation subsidies for implementation of vertical MFF.

\section{Materials and Methods}

\subsection{Study Site}

Kami City is located in Kochi Prefecture in the southern region of Shikoku Island, Japan (Figure 1). It was selected as study site because of five case, context and scale related reasons. First, Kochi Prefecture has the largest percentage of forest area in Japan. Kochi has become significant for the Japanese forest industry. Second, the area of plantations that have reached maturity and that are subject of subsidization is very high. Third, large areas of Japanese red pine (Pinus densiflora) plantations show strong signs of degradation [35], and many older plantations have been overplanted and never been thinned resulting in loss of understory biodiversity. Fourth, the area of fragmented small-scale private forest is exceptionally high. Private small-scale forest owners hold nearly $91 \%$ of the 19,516 ha of forest in Kami. Of these $91 \%$, approximately $75 \%$ are plantations, which almost completely consist of sugi (Cryptomeria japonica) and hinoki (Chamaecyparis obtusa). The majority of these stands have recently, or will soon be reaching merchantability. Fifth, despite merchantability, roundwood prices have been declining critically by over $250 \%$ over the past decades, and have fallen to near average thinning costs. Although prices have stabilized with a slight increasing trend, thinning in sugi stands is especially affected by this negative price development. Close to $100 \%$ of private forest qualifies for, or receives direct financial management support for thinning operations.

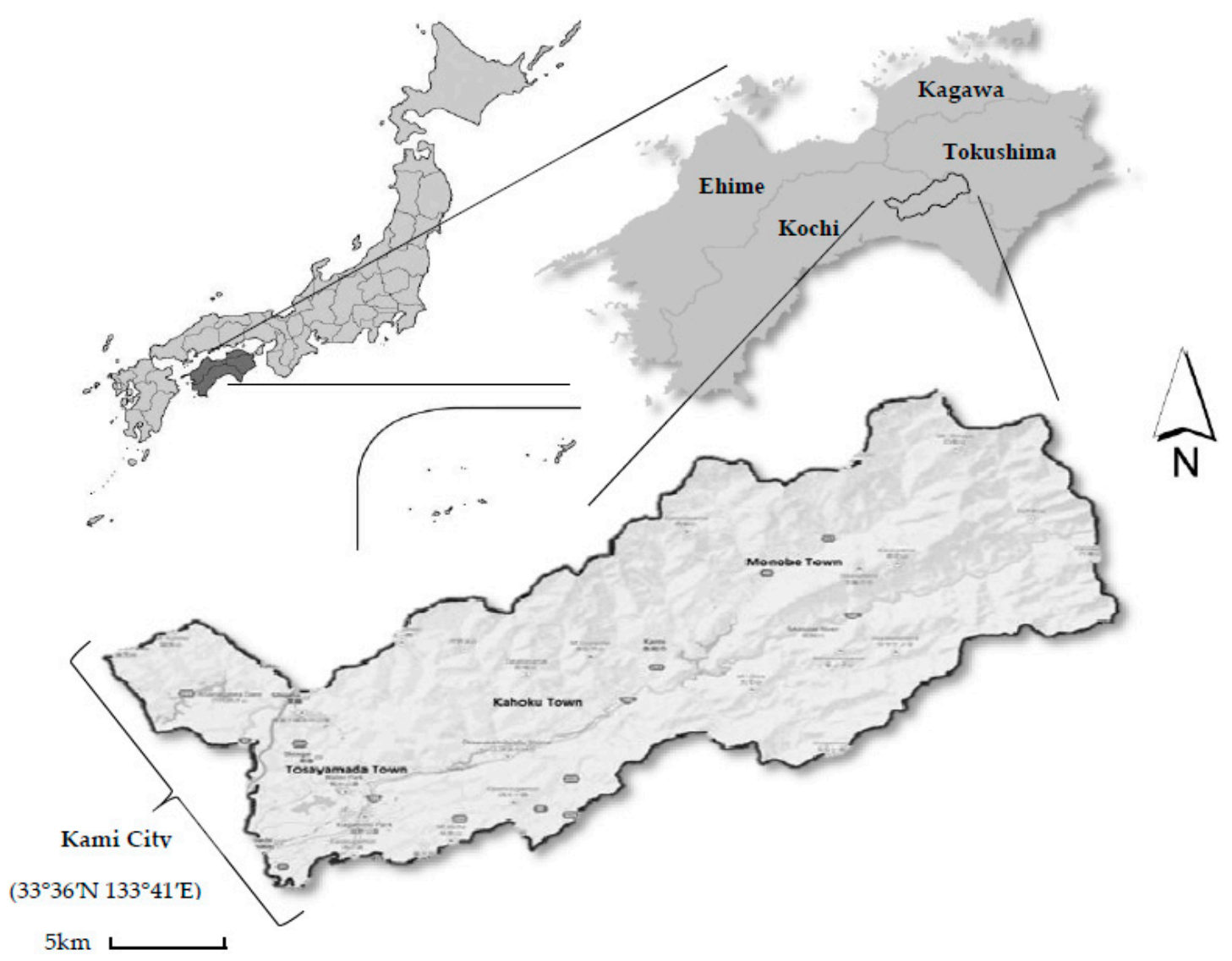

Figure 1. Location of study site (Google Maps). 
Figure 2 shows a flow diagram of the application of the subsidies. More than one public authority provides financial support. In addition, some of these subsidies are exclusively provided in cooperation with the national and prefectural government, while remaining subsidies receive additional support from the municipality government.

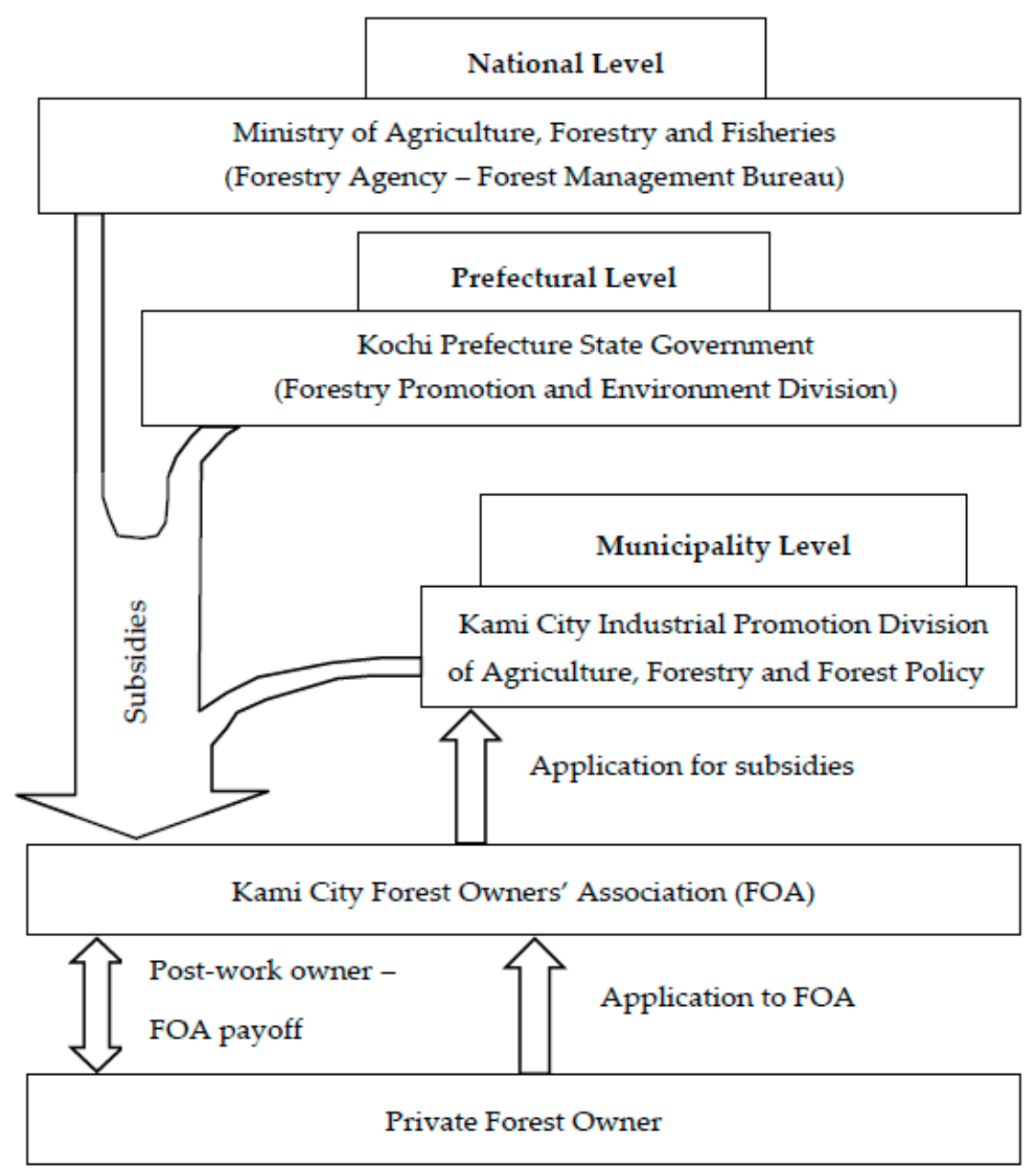

Figure 2. Subsidy application network in Kami City/Kochi Prefecture.

\subsection{Material Collection and Preparation}

Official objective statements and descriptions of currently available forestry subsidies for private forest have been collected from Kochi Prefecture Administration. For verification purposes, the same set of data was collected from Kami Forest Owners' Association where it is used for management negotiation purposes with private forest owners.

According to the collected data, a total of twelve subsidies are currently available. These twelve subsidies were categorized into three groups: G1, G2, G3 according to their administrative characteristics, and structured as follows:

G1: Subsidies for forestation, afforestation, bird habitat protection, shrub removal and stands affected by forest road establishment (Managed under Forest Planning System) (Appendix A Table A1)

G2: Subsidies for self-administered forest management, environmental enhancement and timber production (Appendix A Table A2)

G3: Subsidies for reforestation and protection from wildlife damage (Appendix A Table A3)

Each group was subcategorized for type of forest interventions, applied work descriptions, intervention intensity, stand age requirement, area and general support requirements, as well as 
the subsidy rates. As far as applicable, these rates were further classified into funds from national, prefectural and municipality governments. Irrelevant subsidies addressing infrastructure development, such as road construction, machinery etc. were excluded from this study.

\subsection{Methodology}

A methodology applying focus group discussions (FGD) was followed. In general, focus groups are moderated interacting individuals of common knowledge, that come together to explore and clarify issues on complex issues which may not be possible using other methods [36]. Evaluation of subsidies through FGD are ideal in this case as it explores and explains the complexity of possible long-term future outcomes of subsidized forest works on forest structure development, especially when targeting an enhancement of vertical MFF.

Through FGD, information gained from participants is transferred into a group opinion through interaction by process factors such as cognition, negotiation, generation of knowledge power relations, which are next to learning processes, important FGD criteria [37]. A nonthreatening and relaxed discussion environment supports the acquisition of these cognitive and emotional perceptions [38]. This acquired group opinion provides a means of evaluation to help improve the planning and designing of potentially better performing program alternatives in the future. For instance, FGD were used to evaluate the effectiveness of a government supported networking program in Flanders as a means for effective design of programs of such kind [39]. In similar context, FGD were used in a study in Malawi to evaluate an agricultural subsidy scheme [6]. FGD have also been used to identify influence of subsidies for decisions of landowners regarding sustainable forestry [40]. To maximize elaboration, a reasonable group size for FGDs is important and ranges from four to twelve, depending on the expertise of participants and the complexity of the topic. Smaller groups from five to eight are recommended when participants are experienced with the topic, as larger groups may reduce answer quality such as shortened and trivial answers [41].

FGD of the Kochi Prefecture subsidy scheme for private forest were conducted with experienced forestry practitioners in Japan $(n=6)$, Germany $(n=6)$ and Austria $(n=6)$. To eliminate the risk of lobbyism, practitioners were chosen from different "neutral" forestry related fields, consisting of private and public foresters, forestry researchers, forest owners, forestry workers and engineers, forest pedagogues and forest administrators. This mix of participants from various forestry fields was used to reduce acquiescence bias during the discussions, and to keep group dynamics high for deep and rich discussions. Practitioners from Germany and Austria were included in this evaluation due to local communities in these countries having a long implementation history of sustainable forest management (SFM) and may evaluate differently to the Japanese focus group. In Kami City, the concept of SFM has only recently gained consideration among local stakeholders. Practitioners were clarified about the procedure and were made familiar with the local forest conditions and infrastructure in Kami City. A questionnaire was designed and executed. In this questionnaire, the three general on-site management related NBSJ objectives for private forest (a) Development of diverse forests; (b) Forest conservation and management; and (c) Control of wildlife damage, were selected. Questions targeted the possible direct and indirect influences of the subsidized works on these objectives. Direct influence of a subsidy was demonstrated if site management is expected to contribute to one or more NBSJ objectives. Indirect influence was demonstrated if site management was expected to contribute to one or more NBSJ objectives implicitly, not directly aimed by subsidy statement. No influence was demonstrated if site management is not expected to positively contribute to one or more NBSJ objectives.

\subsection{FGD Data Collection and Analysis}

Data collection and analysis is performed simultaneously in FGD [42]. A combination of framework analysis [41] and constant comparison analysis [43,44] as analytic components, was used. The framework analysis was selected as it is suitable to manage large amounts and complex qualitative 
focus group data [42], which was expected from the dynamic discussions among the mixed group of experts. Constant comparison analysis was adopted as it is a suitable method in multiple-FGD scenarios, as it allows to evaluate thematic saturation across groups. The five stages of framework analysis were applied: familiarization of collected data, identification of theme, indexing, charting and identification. In the indexing and charting stages, the three coding components of Constant Comparison Analysis (open, axial and selective) were applied across the three focus groups. Final data interpretation focused on both individual comments, and their interrelationship with those of others. Interpretations of FGD data were organized as their frequency of occurrence, motion, explicitly, depth and the big picture.

Following FGD, interpretations were discussed and the subsidy scheme was compared to the Bavarian one to give an example of a different approach to achieve vertical MFF.

\section{Results}

Table 1 shows the FGD results for direct and indirect influences of the twelve subsidies S1-S12 (see Appendix A) in groups G1-G3 on the three selected NBSJ forest management objectives. On observation, evaluations by all three focus groups have been performed similarly with main focus towards direct influence of subsidies on NBSJ objective 2-Forest Conservation and Management, and indirect influence of subsidies on NBSJ objective 1-Development of Diverse Forests. Subsidy group G1 shows a different evaluation of the S4-Renewal Thinning subsidy by the Japanese and German groups evaluating it as directly contributing to the development of diverse forest. The Austrian focus group evaluated it as an indirect contributor to this objective. Evaluation of subsidies S10-S12 in subsidy group G3 show different and multiple opinions regarding the influence of these subsidies on NBSJ objectives. These results shall be discussed alongside selected critical comments and suggestions by the focus groups for possible ways to improve the current subsidy scheme.

Table 1. FGD results for direct and indirect subsidy influence on NBSJ objectives-Japan (J); Austria (A) and Germany $(\mathrm{G})$.

\begin{tabular}{|c|c|c|c|c|c|c|}
\hline \multirow[t]{2}{*}{ Type of Subsidy (S) } & \multicolumn{2}{|c|}{$\begin{array}{l}\text { Development of } \\
\text { Diverse Forests }\end{array}$} & \multicolumn{2}{|c|}{$\begin{array}{l}\text { Forest Conservation } \\
\text { and Management }\end{array}$} & \multicolumn{2}{|c|}{$\begin{array}{l}\text { Control of Wildlife } \\
\text { Damage to Forests }\end{array}$} \\
\hline & Direct & Indirect & Direct & Indirect & Direct & Indirect \\
\hline \multicolumn{7}{|l|}{$\begin{array}{l}\text { (G1) Subsidies for forestation, afforestation, } \\
\text { bird habitat protection, shrub removal and } \\
\text { stands affected by forest road establishment }\end{array}$} \\
\hline 1. Improvement thinning & & J A G & J A G & & & \\
\hline 2. Early thinning & & J A G & J A G & & & \\
\hline 3. Commercial thinning & & J A G & $\mathrm{J} \mathrm{A} \mathrm{G}$ & & & \\
\hline 4. Renewal thinning & J G & A & J A G & & & \\
\hline 5. Thinning for environmental development & & J A G & J A G & & & \\
\hline \multicolumn{7}{|l|}{$\begin{array}{l}\text { (G2) Subsidies for self-administered forest } \\
\text { management, environmental enhancement } \\
\text { and timber production }\end{array}$} \\
\hline 6. Commercial thinning & & J A G & J A G & & & \\
\hline 7. Improvement thinning & & J A G & J A G & & & \\
\hline 8. Early thinning & & J A G & J A G & & & \\
\hline 9. Thinning & & J A G & J A G & & & \\
\hline \multicolumn{7}{|l|}{$\begin{array}{l}\text { (G3) Subsidies for reforestation and protection } \\
\text { from wildlife damage }\end{array}$} \\
\hline 10. Reforestation & A G & $\mathrm{J}$ & J A G & & $\mathrm{J}$ & \\
\hline 11. Protection from deer damage ${ }^{a}$ & $\mathrm{~J}$ & G & A G & & J A G & \\
\hline 12. Shrub removal & & A G & A G & $\mathrm{J}$ & & \\
\hline
\end{tabular}

\subsection{Summary of Critical Group Comments and Suggestions}

(1) Concern on effectiveness of subsidy scheme for the development of diverse forest

"Subsidies S1-12 possibly can-if applied with adequate care and knowledge of ecological correlations-lead to higher diversity in mixed forests, however it is not very likely in 
monocultures unless surrounding species have a chance to rejuvenate in a stand that was recently thinned. All subsidies will probably have a direct positive effect on forest conservation and management of existing stands." (German focus group)

This comment by the German group of experts can be explained by means of subsidy statements. Management measures of subsidies S1-5 target three major intervention strategies: removal of low quality timber, unmarketable timber, and contaminated timber. Each measure is based on stand age and median diameter at breast height (DBH). S3, S4 and S5 support removal of marketable timber. While S1 and S2 target enhancement of forest development, specific nature development goals are not mentioned, raising the concern that subsidies S1 and S2 contribute to the development of monocultures for improvement of economic efficiency. S10 does not clearly separate species and their distribution that qualify for this subsidy.

(2) Concern of effectiveness of improvement thinning for the development of diverse forest

"Subsidies for improvement thinning (S1, S7) can bring positive effects for forest conservation and management. However, the effect regarding the development of diverse forests should be low or in cases even negative. The planned measures such as removal of low quality trees suggest a uniform type of forest, likely consisting of few species and/or monetarily valuable species, and/or low age difference and/or less diverse tree shapes. It is also unclear what is meant by "quality". Quality regarding industrial utilizability, natural conservation or soil protection?"

Suggestion: "If development of diverse forest is desired, it should be clearly formulated in the subsidy statement. Forest works should include access to measures such as the planting of additional species." (German focus group)

Comments and suggestions by the German focus group point out the possibility of a loss of diversity for works associated with current improvement thinning subsidies S1 and S7. Detailed formulation of subsidy statements and forest works for the development of diverse forest is an important suggestion to ensure correct implementation of multi-species management.

(3) Criticism for the way of renewal thinning

"Although conversion to a mixed-culture can be achieved, we criticize the current intensity for the subsidy for renewal thinning (S4). A sudden extensive thinning can result into the conversion of a well-balanced mixed stand into a monoculture, in the event seed trees not being sufficiently available."

Suggestion: "A thinning should be planned to incorporate flexible intensity and the level of tree maturity. On-site assessment is necessary to make sure species develop and rejuvenate as planned." (German focus group)

Comments by the German focus group regarding renewal thinning suggest careful planning of the extraction of tree species to avoid loss of diversity. The level of tree maturity and ability to rejuvenate must be taken into account when planning and executing thinning works. On-site assessment is needed to control and monitor implementation of such management.

(4) Concern regarding commercial thinning

"If in commercial thinning only well marketable trees are removed, stand structure will change. However, it may lead to both, an increase or decrease of biodiversity. If mainly one tree species is removed, it will affect biodiversity. If a balance of several tree species is removed, biodiversity is likely to increase and other more indigenous species get a chance to spread."

Suggestion: "On-site assessment is important to make sure the latter." (Austrian focus group) 
(5) Concern regarding forest establishment and bird habitat protection

"Subsidies for forestation, afforestation, bird habitat protection and stands affected by forest road establishment are not sufficiently addressed, given most subsidies targeting thinning. Although an indirect positive effect is likely to be achieved, there should be separate subsidies or measures that directly target these goals."

Suggestion: "For the development of diverse forests, there should be a clear definition if and how broadleaf species qualify for reforestation." (German focus group)

(6) Suggestion for wildlife management and natural rejuvenation

"S11 has potential to reduce wildlife damage through appropriate protective measures. If browsing causes increased damage, renewal thinning with followed natural rejuvenation can lead to increased food availability, and as a result reduce young tree damage by browsing."

Suggestion: "Such an approach should be explained in subsidies in more detail." (Austrian focus group)

Evaluation of S11 Control of Wildlife Damage to Forests was comparable in each nation. The reason for this answer can be explained as: (1) an increase of forestland also increases the amount of available food sources which likely results into a reduction of damage by browsing in small areas. (2) The direct application of artificial tree protection is part of this subsidy. However, the approach as suggested by the Austrian focus group could be considered as a natural low cost alternative. Yet, such an approach would require regular on-site assessment.

(7) Necessity of the subsidy scheme in its current form

"The subsidy scheme creates consensus with owners. Given current low roundwood prices, subsidies are necessary to meet annual logging goals. Without subsidies most owners would not agree to any type of management that would require private investment." (Japanese focus group)

\subsection{Contrast to Bavarian Subsidy Scheme for Private Forest}

Similar to the Kochi subsidy scheme the Bavarian scheme for private forest aims at the conservation of forest resources and health, the preservation of multifunctionality and climate tolerance [45]. Both schemes were designed to implement national goals for the establishment of diverse forests with the Bavarian scheme further referring to EU sustainability regulations. In the Bavarian scheme, promotion focuses on the establishment and redesign of coniferous monocultures into site-adapted climate tolerant mixed- and broadleaf forest by planting and/or natural rejuvenation. In all cases, broader sustainability issues are covered.

The promotion of broadleaf forest receives the highest financial support, coniferous forests are supported only on specifically designated sites in which coniferous species have been and should be naturally present. Stand and forest floor management incorporates support for tending for stands younger than fifteen years. Natural rejuvenation is favored. The type and number of trees, rather than area determine afforestation practices. The advantage of natural rejuvenation and single-tree management, is the possibility for managers to apply close-to-nature forestry to manage sites with higher structure flexibility. For instance: species mixing, density and layer management, correction of insufficiently naturally rejuvenated areas, and inventory repair after windthrow, pest and other natural hazards. Adequate soil management further supports the successful establishment of sustainable forest. Measures for pest control are granted based on site assessment.

Extraction from stands that require the use of cost intensive skyline systems such as in mountain forest and especially wetlands receive cost compensation. Merchantable timber is not limited to 
tree age and log diameters which allows longer rotation periods. To ensure equal treatment of all forest functions, integrative forest function management is encouraged and supported, including the preservation of rare, local and site adapted species, old seed trees, wetlands and other specially designated habitats. Soil protective extraction is supported by the use of horse, traction winch and small-sized tower yarders. Partial support is granted in the event of flood and forest fire damage. Commercial extraction receives no financial support. A summary of main financial support by the Bavarian and Kochi subsidy schemes is presented in Table 2.

Table 2. Summary of main financial support by Kochi and Bavaria subsidy schemes.

\begin{tabular}{lll}
\hline Type of Financial Support & Kochi Scheme & Bavaria Scheme \\
\hline First time afforestation & No & Yes \\
Promotion of coniferous species & by forest area & by no. of trees on designated sites \\
Promotion of broadleaf species & No & by no. of trees \\
Promotion of species mixing & No & Yes \\
Promotion of monocultures & Yes & No \\
Promotion of site-adaptive management & No & Yes \\
Preference of natural rejuvenation & Not mentioned & Yes \\
Commercial extraction & $30 \%$ intensity & On designated sites soil preserving strategies \\
Non-commercial thinning & $30 \%$ intensity & On designated sites per area \\
Soil conservation & No & Yes \\
Protection from harmful organisms & No & Yes \\
Protection from wildlife damage & Yes & No \\
Integrative forest management & No & Yes \\
Fire and water damage & No & Yes \\
\hline
\end{tabular}

\subsection{Integrative vs. Segregative Management}

In comparison to the Kochi subsidy scheme, the Bavarian scheme incorporates wider measures necessary for the establishment of site-adapted climate tolerant mixed- and broadleaf forest based on forest development strategies. These measures are key components of integrative forest management for achieving multifunctionality. In the case of Kami, as focus group evaluation suggests, the subsidies do not effectively contribute to the scheme objective that targets multifunctional forestry, so arguably not an effective integrative approach. The terms multifunctionality and environmental preservation in the subsidy objective statements are too broad to be achieved by mainly thinning works. Therefore, with this scheme, a segregation of forest functions towards commercial use of forest rather than sustainable integration of functions is observable.

Forest function segregation can often be observed in various economic, logistic and socio-demographic environments, such as (1) Economic pressure because of low timber prices or high harvesting costs; (2) rapidly increasing timber demand; (3) difficult to access forest; (4) population decrease; and (5) insufficient engagement by forest owners. All these five examples for segregation could be observed in Kami City. Production costs are close to timber price, for especially sugi; annually set logging goals by the government are increasing; wide areas of private forest are difficult to access due to a still not sufficiently developed forest road network, and construction difficulty of roads due to complex topographical conditions; and a very large distribution of small-scale forest owners. Segregation of forest functions brings a number of ecological disadvantages: important ecological management aspects become neglected, and a tendency to even-aged coniferous monoculture approaches which lead to a reduction of rotation time can be observed. In such even-aged monocultures natural capital can become even negative when, for instance, root density affects water and air productivity of the soil. Especially in specific nature protection areas, the protection of natural resources can be significantly affected by root density. The social recreation aspect can also be affected by segregation. For instance, forests that are designed and managed to allow extensive use of machinery often offer little optical incentives for a visit [46]. 


\subsection{Proposal to Improve Subsidies for Achieving NBSJ Objectives}

A proposal shall be made for the improvement of the Kochi subsidy scheme towards integrative management of forest functions. This proposal incorporates expert comments and suggestions, and possible applicable strategies from the Bavarian subsidy scheme into account by considering local conditions, and the general need for subsidies to meet annual logging goals.

\subsubsection{Role of Subsidy Scheme}

Japan's legal framework does not allow the passing of legally binding prefecture-level forest laws, and national forest policy addresses SFM in an undetailed sense [47]. The current subsidy scheme is an on national level designed tool to contribute to achieving NBSJ objectives. To improve forest conditions locally, concrete guidelines for the establishment of forest structure and its management in Kochi, as suggested by the German and Austrian group of experts, should be introduced to the current subsidy scheme to achieve NBSJ objectives. To achieve this, an extension of subsidy scope becomes necessary which should be planned and implemented by local forest managers.

\subsubsection{Scope and Formulation of Subsidy Scheme}

Strategies regarding how mixed stands are subject to financial support should be formulated more clearly with terminology regarding the improvement of "quality" being formulated in more detail. These strategies should then be accompanied by defined guidelines in which clear statements are given regarding forest development varieties, mixed stand establishment and the respective management. Such guidelines have to be formulated also within subsidy statements targeting thinning regimes for the involvement of respective underplanting of new species, as well as reforestation. The guidelines can be summarized in six points: (1) Natural rejuvenation as a strategy to increase food availability for food ability for forest protection from wildlife damage must be considered and explained in detail. (2) Support for the preservation of rare and threatened species, as well as naturally valuable locations must be added to degeneralize the terminology of forest. In addition, subsidies addressing forestation, afforestation and bird habitat protection should be separated and practical measures should be specifically adapted. (3) To avoid risks during and after thinning operations, and to ensure an effective increase of biodiversity, regular qualified on-site assessment needs to be introduced. (4) Stand age limitation for the applicability of measures should be removed to allow permanent-cover strategies as alternatives to clear-cuts for forest owners. (5) The use of skyline thinning systems and other forest soil protective extraction strategies should be promoted separately from those implying higher risks for forest floor damage. This should be further supported by risk mapping of areas that are very sensitive to erosion and cost-intensive measures to stabilize these areas should be supported separately. (6) In the current case of Kochi, commercial extraction receives identical, and in some cases even higher financial support than thinning for forest preservation. Justification for financial support for commercial extraction should be present in detail in the subsidy statement to provide transparency.

\section{Discussion and Conclusions}

Reflecting results of the focus group evaluations, the present subsidy scheme for private forest in Kami City/Kochi Prefecture suggests focus on the revitalization or regeneration of existing single layered coniferous plantations by subsidizing capable forest works. This is a fundamental issue of Japanese forest policy in regards to realizing vertical MFF in private plantations. Although all landscapes can more or less be considered multifunctional [48], regeneration does usually not explicitly consider this. A regeneration strategy lacks multifunctional philosophy, ignoring the full potential for natural-capital [24] especially from a long-term perspective.

Based on FGD findings, the analyzed subsidy scheme supports spatial segregation of forest functions among natural forest and plantations, insufficiently addressing vertical MFF objectives of the NBSJ in plantations. Concern was raised that practical measures in the current subsidization 
strategy could result into loss of biodiversity. Up to $72 \%$ of cost is subsidized; a rate close to average in Asia [3]. However, while research has shown stakeholder understanding for the importance of MFF [2], at such a high rate, and without access to alternative MFF options, private forest owners are seemingly obligated to maintain, expand or even develop new areas of even-aged forest.

Most of current on-site management is carried out to qualify for financial support without long-term perspectives [49]. Decision-making processes aiming the long-term development of site characteristics are needed to achieve sustainable forestry in the way the Japanese government promotes it.

For forest policy to be effective in improving vertical MFF, institutional drivers must be designed to motivate forest owners to change their behavior corresponding to forest policy objectives [50]. To do so, a deeper understanding of private forest owners is necessary to improve the linkage of current forest practices to biodiversity requirements [51]. In addition, to achieve the desired environmental benefits as promoted by the NBSJ, the subsidy scheme itself requires adjustment and should include measures that directly lead to integrative multifunctional management. One way should be to allow planning at local/regional-level as it is considered most appropriate for sustainability [52]. A lot of multifunctionality can be found at this level, therefore planning-processes should integrate sites into the general landscape [53]. This has to be supported by concrete management advice and research on silviculture, plantation management, and the utilization of multispecies forests.

The six-point proposal made to restructure the current subsidy scheme in Kochi Prefecture/Kami City, can be used as a model for local, long-term enhancement of vertical MFF in Japanese private plantations. Regular sustainability on-site assessment, as suggested by the focus groups, will be the crucial aspect for successful implementation. This approach has the potential of enhancing local forest policy to balancing environment and production at local level as demanded by previous research in Japan [54]. Balancing production and environment is capable of not only supporting the Japanese forest industry to stand on its own, but to sustainably benefit society as a whole by also protecting environmental values, the way it is promoted by the NBSJ.

However, the approach of this study is not without shortcomings. Forest owners hold a uniquely strong key position in Japan as forest law is currently not enforceable, and shows more characteristics of a general framework rather than implementation plan for Japan's forestry vision [47]. A subsidy scheme that was appropriately planned and organized, and which is likely to improve vertical MFF, may simply fail because forest owners will not accept it. In addition, unlike other industrialized nations, most areas in Japan do not yet have access to qualified foresters that would be capable of coordinating the wants and needs of local stakeholders, especially forest owners. Consequently, a plan for an improved subsidy scheme that targets forest works alone may not be sufficient under the current law. Incorporating experts and law makers specialized in forest legislature in the FGD may have resulted to important additional interpretations for proposals for improvement of the analyzed subsidy scheme in Kochi Prefecture. Future studies on the topic should analyze the benefits of a combination of subsidies for forest works and subsidies for forest non-commodity goods (services), for improving vertical MFF in small-scale private plantations under scenarios of unenforceable forest law. Studies in specifically Japan should further analyze the benefits and applicability of vertical MFF in both natural forest and plantations.

Acknowledgments: The authors wish to thank Nojima, Mitani and Tanabe at Kami Forest Owners' Association for their kind assistance with data collection and encouragement throughout this study. We would also like to express our sincere gratitude to Toda, Schönherr and Yamasaki of Kochi Prefectural Forestry Information and Technology Research Center, and all members of 21st Century Forest and Water Association for their constant assistance. The authors and Kochi University of Technology gratefully acknowledge all additional support.

Author Contributions: D.G. designed the research, conducted the focus group discussions in Japan, Austria and Germany and analyzed the data. T.W. contributed with research design, analysis tools and research structure. D.G. wrote the paper.

Conflicts of Interest: The authors declare no conflict of interest. 


\section{Appendix A}

Table A1. Subsidies for forestation, afforestation, bird habitat protection, shrub removal and stands affected by forest road establishment under forest management (FM) plans.

\begin{tabular}{|c|c|c|c|c|c|c|c|}
\hline $\begin{array}{l}\text { Type of } \\
\text { Subsidy (S) }\end{array}$ & $\begin{array}{l}\text { Stand Age } \\
\text { (Years) }\end{array}$ & $\begin{array}{l}\text { Type of } \\
\text { Management }\end{array}$ & $\begin{array}{l}\text { Area } \\
\text { (ha) }\end{array}$ & $\begin{array}{l}\text { Intensity } \\
\text { (Thinning) }\end{array}$ & Support Requirements & $\begin{array}{l}\text { Subsidy Rate } \\
(\mathrm{N}, \mathrm{P})^{\mathrm{a}}\end{array}$ & $\begin{array}{l}\text { Subsidy Rate } \\
\text { (M) b }\end{array}$ \\
\hline $\begin{array}{l}\text { 1. Improvement } \\
\text { thinning }\end{array}$ & $\sim 25$ & $\begin{array}{l}\text { Negative selection } \\
\text { of low quality and } \\
\text { infectious trees }\end{array}$ & $0.1+$ & $\begin{array}{l}\text { Not applicable } \\
\text { (N/A) }\end{array}$ & $\begin{array}{l}\text { Stands approved for } \\
\text { FM Scheme }\end{array}$ & $68 \%$ & 10,000 Yen/ha \\
\hline $\begin{array}{l}\text { 2. Early } \\
\text { thinning }\end{array}$ & $\sim 35$ & $\begin{array}{l}\text { Negative selection } \\
\text { of low quality and } \\
\text { infectious trees }\end{array}$ & $0.1+$ & $30 \%$ & $\begin{array}{l}\text { Stands approved for } \\
\text { Silviculture Scheme }\end{array}$ & $68 \%$ & 10,000 Yen/ha \\
\hline $\begin{array}{l}\text { 3. Commercial } \\
\text { thinning }\end{array}$ & $\sim 60$ & $\begin{array}{l}\text { removal of } \\
\text { marketable wood } \\
\text { without negative } \\
\text { selection }\end{array}$ & $\begin{array}{l}0.1+ \\
(5+)^{\mathrm{c}}\end{array}$ & $30 \%$ & $\begin{array}{l}\text { Stands approved for } \\
\text { FM scheme }\end{array}$ & $68 \%$ & $1000 \mathrm{Yen} / \mathrm{m}^{3}$ \\
\hline $\begin{array}{l}\text { 5. Thinning for } \\
\text { environmental } \\
\text { development }\end{array}$ & $\sim 60$ & $\begin{array}{l}\text { Negative selection } \\
\text { of low quality and } \\
\text { infectious trees }\end{array}$ & $0.1+$ & $30 \%$ & $\begin{array}{l}\text { No public forest unless } \\
\text { contracted out to } \\
\text { private person } \\
\text { No forest held by forest } \\
\text { owners' associations or } \\
\text { non-governmental } \\
\text { organizations unless } \\
\text { contracted out to a } \\
\text { private person }\end{array}$ & $\begin{array}{l}36 \% \\
72 \% d\end{array}$ & 10,000 Yen/ha \\
\hline
\end{tabular}

\footnotetext{
Notes: ${ }^{a}$ N: National government; P: Prefectural government; ${ }^{b}$ M: Municipality government; ${ }^{c}$ Stands under forest management implementation plan in the business of a particular thinning promotion plan based on the Special Measures Law; ${ }^{\mathrm{d}}$ Stand must be expected to deliver high environmental benefit.
}

Table A2. Subsidies for self-administered forest management, environmental enhancement and timber production.

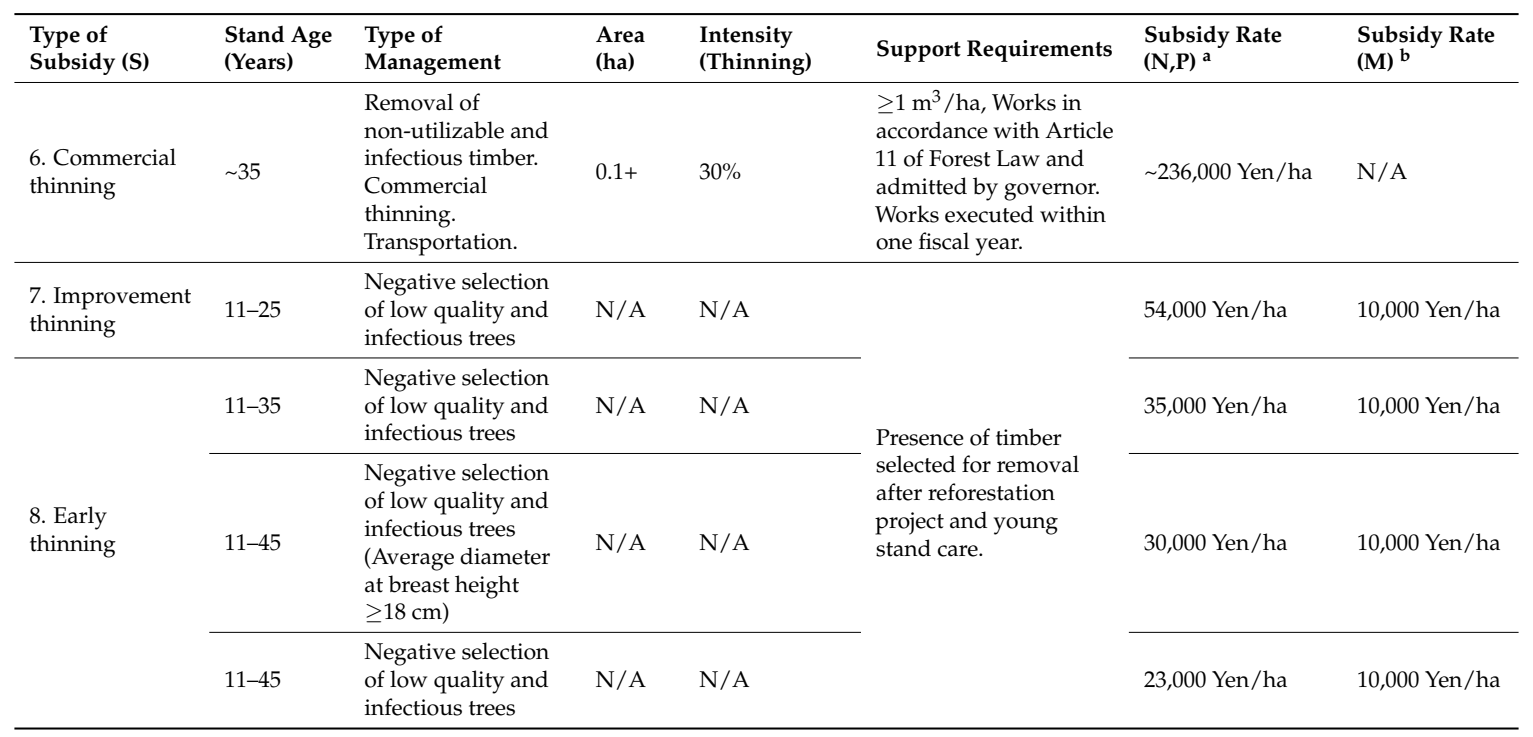


Table A2. Cont.

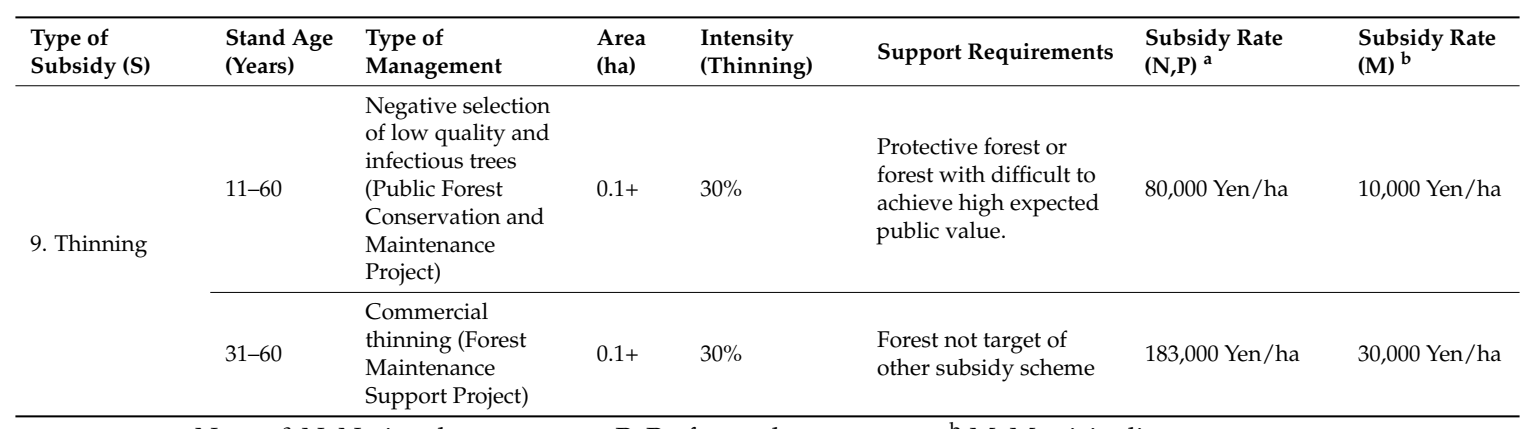

Notes: ${ }^{a} \mathrm{~N}$ : National government; P: Prefectural government; ${ }^{\mathrm{b}}$ M: Municipality government.

Table A3. Subsidies for reforestation and protection from wildlife damage.

\begin{tabular}{|c|c|c|c|}
\hline Type of Subsidy (S) & Support Requirements & $\begin{array}{l}\text { Subsidy Rate } \\
(\mathrm{N}, \mathrm{P})^{\mathrm{a}}\end{array}$ & $\begin{array}{l}\text { Subsidy Rate } \\
\text { (M) b }\end{array}$ \\
\hline 10. Reforestation & \multirow{3}{*}{$\begin{array}{l}\text { Works administered by third party. } \\
\text { S11 and S12 are carried out } \\
\text { in combination }\end{array}$} & \multirow{3}{*}{$68 \%$} & \multirow{3}{*}{$\sim 22 \%$} \\
\hline 11. Protection from deer damage & & & \\
\hline 12. Shrub removal & & & \\
\hline
\end{tabular}

\section{References}

1. Food and Agriculture Organization of the United Nations. Planted Forests in Sustainable Forest Management: A Statement of Principles. 2010. Available online: http://www.fao.org/docrep/012/al248e/al248e00.pdf (accessed on 31 January 2017).

2. Nijnik, M.; Nijnik, A.; Brown, I. Exploring the linkages between multi-functional forestry goals and the legacy of spruce plantations in Scotland. Can. J. For. Res. 2016, 46, 1247-1254. [CrossRef]

3. Bull, G.Q.; Bazett, M.; Schwab, O.; Nilsson, S.; White, A.; Maginnis, S. Industrial forest plantation subsidies: Impacts and implications. For. Policy Econ. 2006, 9, 13-31. [CrossRef]

4. Ciccarese, L.; Mattsson, A.; Pettenella, D. Ecosystem services from forest restoration: Thinking ahead. New For. 2012, 43, 543-560. [CrossRef]

5. Dana, S.T. Multiple use, biology and economics. J. For. 1943, 41, 625-627.

6. Dorward, A.; Chirwa, E.; Kelly, V.A.; Jayne, T.S.; Slater, R.; Boughton, D. Evaluation of the 2006/2007 Agricultural Input Subsidy Programme, Malawi; Final Report; Food Security Collaborative Working Papers; Department of Agricultural, Food, and Resource Economics, Michigan State University: East Lansing, MI, USA, 2008; Available online: http:/ / ageconsearch.tind.io/record/97143/files/AISPFinalReport31March.pdf (accessed on 31 January 2017).

7. Enters, T.; Durst, P.B.; Brown, C.; Carle, J.; McKenzie, P. What Does It Take? The Role of Incentives in Forest Plantation Development in Asia and the Pacific; Food and Agriculture Organization of the United States: Bangkok, Thailand, 2004; Available online: http://bibliotecavirtual.minam.gob.pe/biam/handle/minam/ 1327 (accessed on 31 January 2017).

8. Pearson, P. Energy, externalities and environmental quality: Will development cure the ill it creates? Energy Stud. Rev. 1994, 6, 199-216. [CrossRef]

9. The Organisation for Economic Co-operation and Development. Multifunctionality: Towards and Analytical Framework; OECD: Paris, France, 2001.

10. Pawson, S.M.; Brin, A.; Brockerhoff, E.G.; Lamb, D.; Payn, T.W.; Paquette, A.; Parrotta, J.A. Plantation forests, climate change and biodiversity. Biodivers. Conserv. 2013, 22, 1203-1227. [CrossRef]

11. Ostrom, E. A general framework for analyzing sustainability of social-ecological systems. Science 2009, 325, 419-422. [CrossRef] [PubMed]

12. Krott, M. Forest Policy Analysis; Kluwer Academic Publisher: Dordrecht, The Netherlands, 2005.

13. Bär, H.; Jacob, K.; Meyer, E.; Schlegelmilch, K. Wege zum Abbau umweltschädlicher Subventionen; Abteilung Wirtschafts-und Sozialpolitik der Friedrich-Ebert-Stiftung: Bonn, Germany, 2011. 
14. Goetzl, A. Subsidy or incentive? ITTO Trop. For. Update 2006, 16, 3. Available online: http://www.itto.int/ $\mathrm{tfu} / \mathrm{id}=27100000$ (accessed on 31 January 2017).

15. Robin, S.; Walcott, R.; Quintela, C.E. Perverse subsidies and the implications for biodiversity: A review of recent findings and the status of policy reforms. In Proceedings of the Sustainable Finance Stream, Fifth World Parks Congress, Durban, South Africa, 8-17 September 2003.

16. Schmid, E.; Sinabell, F.; Hofreither, M.F. Phasing out of environmentally harmful subsidies: Consequences of the 2003 CAP reform. Ecol. Econ. 2007, 60, 596-604. [CrossRef]

17. Porter, G. Subsidies and the environment: An overview of the state of knowledge. In Proceedings of the OECD Workshop on Environmentally Harmful Subsidies, International Energy Agency, Paris, France, 7-8 November 2002; Available online: http://www.oecd.org/site/agrehs/35217152.pdf (accessed on 31 January 2017).

18. Hunter, M. (Ed.) Maintaining Biodiversity in Forest Ecosystems; Cambridge University Press: Cambridge, UK, 1999.

19. Barrett, A.; Trace, F. The Impact of Agricultural and Forestry Subsidies on Land Prices and Land Uses in Ireland; The Economic and Social Research Institute: Dublin, Ireland, 1999.

20. Berg, H.; Burger, A.; Thiele, K. Environmentally Harmful Subsidies in Germany; Federal Environment Agency: Dessau, Germany, 2011.

21. Knirsch, J.; Mittler, D.; Kaiser, M.; Sack, K.; Thies, C.; Edwards, L. Deadly Subsidies; Greenpeace International: Amsterdam, The Netherlands, 2006.

22. Pearce, D. Environmentally harmful subsidies: Barriers to sustainable development. In Proceedings of the OECD Workshop on Environmentally Harmful Subsidies, International Energy Agency, Paris, France, 7-8 November 2002; Available online: http:/ / www.oecd.org/site/agrehs/35215571.pdf (accessed on 31 January 2017).

23. Bruvoll, A.; Skjelvik, J.M.; Vennemo, H. Reforming Environmentally Harmful Subsidies: How to Counteract Distributional Impacts; Nordic Council of Ministers: Copenhagen, Denmark, 2011.

24. Urban Task Force. Towards and Urban Renaissance; DETR: London, UK, 1999.

25. Heikkinen, I. Saving Nature for People, National Strategy and Action Plan for Conservation and Sustainable Use of Biodiversity in Finland 2006-2016; Ministry of the Environment: Helsinki, Finland, 2007.

26. Ministry of the Environment (MOE). The National Biodiversity Strategy of Japan 2012-2020; The Ministry of the Environment: Tokyo, Japan, 2012.

27. Jäckel, A.; Roth, M. Conversion of single-layered scots pine monocultures into close-to-nature mixed hardwood forests: Effects on parasitoid wasps as pest antagonists. Eur. J. For. Res. 2004, 123, $203-212$. [CrossRef]

28. Ministry of Agriculture, Forestry and Fisheries (MAFF). Annual Report on Forest and Forestry in Japan for FY2010; Ministry of Agriculture, Forestry and Fisheries: Tokyo, Japan, 2011.

29. Niskanen, A.; Lunnan, A.; Ota, I. Policies affecting forestry entrepreneurship. Small Scale For. 2007, 6, $233-255$. [CrossRef]

30. Ministry of Agriculture, Forestry and Fisheries (MAFF). Annual Report on Forest and Forestry in Japan for FY2012; Forestry Agency, Policy Planning Division: Tokyo, Japan, 2013.

31. Fujisawa, $\mathrm{H}$. The forest planning system in relation to the forest resource and forestry policies. J. For. Res. 2004, 9, 1-5. [CrossRef]

32. Ministry of Agriculture, Forestry and Fisheries (MAFF). Annual Report on Forest and Forestry in Japan for FY2011; Forestry Agency, Policy Planning Division: Tokyo, Japan, 2012.

33. Sayer, J.; Chokkalingam, U.; Poulsen, J. The restoration of forest biodiversity and ecological values. For. Ecol. Manag. 2004, 201, 3-11. [CrossRef]

34. Komatsu, T.; Nakaya, S.; Uraiwong, P.; Watanabe, T. Multi-Stakeholder Mental Model in Monobe River Improvement and Maintenance. 2012. Available online: http:/ /jairo.nii.ac.jp/0042/00000826 (accessed on 31 January 2017).

35. Matsushita, B.; Xu, M.; Onda, Y.; Otsuki, Y; Toyota, M. Detecting forest degradation in Kochi, Japan: Ground-based measurements versus satellite (Terra/ASTER) remote sensing. Hydrol. Processes 2010, 24, 588-595. [CrossRef]

36. Van Giersbergen, M.Y.; Ozsaker, E.; Dirimese, E.; Alcan, A.O. The operating room experiences of nursing students: A focus group study. J. PeriAnesthesia Nurs. 2016, 31, 146-153. [CrossRef] [PubMed] 
37. Kraaijvanger, R.; Almekinders, C.J.M.; Veldkamp, A. Identifying crop productivity constraints and opportunities using focus group discussions: A case study with farmers from Tigray. NJAS Wagening. J. Life Sci. 2016, 78, 139-151. [CrossRef]

38. Wyatt, T.H.; Krauskopf, P.B.; Davidson, R. Using focus groups for program planning and evaluation. J. Sch. Nur. 2008, 24, 71-82. [CrossRef] [PubMed]

39. Van Cauwenberge, P.; Bauwhede, H.V.; Schoonjans, B. An evaluation of public spending: The effectiveness of a government-supported networking program in Flanders. Environ. Plan. C Gov. Policy 2013, 31, 24-38. [CrossRef]

40. Jacobson, M.G.; Straka, T.J.; Greene, J.L.; Kilgore, M.A.; Daniels, S.E. Financial incentives for practicing sustainable forestry on private forest lands. In Our Woods Wild and Working, Proceedings of the 2006 Society of American Foresters National Convention, Pittsburgh, PA, USA, 25-29 October 2006; Society of American Foresters: Bethesda, MD, USA, 2006.

41. Krueger, R.A.; Casey, M.A. Focus Groups: A Practical Guide for Applied Research, 3rd ed.; Sage Publications Inc.: Thousand Oaks, CA, USA, 2000.

42. Rabiee, F. Focus-group interview and data analysis. Proc. Nutr. Soc. 2004, 63, 655-660. [CrossRef] [PubMed]

43. Glaser, B.G. Theoretical Sensitivity; Sociology Press: Mill Valley, CA, USA, 1978.

44. Onwuegbuzie, A.J.; Collins, K.M.T. A typology of mixed methods sampling designs in social science research. Qual. Rep. 2007, 12, 281-316.

45. StMELF. Richtlinie für Zuwendungen zu Waldbaulichen Maßnahmen im Rahmen eines Forstlichen Förderprogramms WALDFÖPR 2014; Bavarian State Ministry of Food, Agriculture and Forestry: Bavaria, Germany, 2014.

46. Bechter, W.; Hüttl, B.; Kemmer, G.; Sippel, A.; Wohlschlegel, F. Integrative Waldwirtschaft versus Segregation der Waldfunktionen; Positionspapier des Vereins für Forstliche Standortskunde und Forstpflanzenzüchtung e.V.: Freiburg, Germany, 2006.

47. Gain, D.; Watanabe, T. The Contribution of Forest Regulations on the Realization of Sustainable Forest Management: A Comparative Law Study of Japan and Germany. 2013. Available online: http:/ /jairo.nii.ac. jp/0042/00000946/en (accessed on 31 January 2017).

48. Fry, G.L.A. Multifunctional landscapes-Towards transdisciplinary research. Landsc. Urban Plan. 2001, 57, 159-168. [CrossRef]

49. Fuchigami, Y.; Hara, K.; Uwasu, M.; Kurimoto, S. Analysis of the mechanism hindering sustainable forestry operations: A case study of Japanese forest management. Forests 2016, 7, 182. [CrossRef]

50. Boon, T.E.; Meilby, H. Describing management attitudes to guide forest policy implementation. Small Scale For. 2007, 6, 79-92. [CrossRef]

51. Matyssek, R.; Clarke, N.; Cudlin, P. (Eds.) Climate Change, Air Pollution and Global Challenges, Understanding and Perspectives from Forest Research (Developments in Environmental Science); Elsevier: Amsterdam, The Netherlands, 2013; Volume 13, pp. 2-622.

52. Forman, R. Land Mosaics: The Ecology of Landscape and Regions; Cambridge University Press: Cambridge, UK, 1995.

53. Moore, H.M.; Fox, H.R.; Elliot, S. Land Reclamation-Extending Boundaries: Proceedings of the Seventh International Conference; CRC Press: Runcorn, UK, 2003.

54. Ota, I. Forest Law and Policy Developments in Japan; Working Papers; International Series 10/1; Department Environmental Sciences, Swiss Federal Institute of Technology Zurich, ETH: Zurich, Switzerland, 2011; pp. 3-11.

(C) 2017 by the authors. Licensee MDPI, Basel, Switzerland. This article is an open access article distributed under the terms and conditions of the Creative Commons Attribution (CC BY) license (http://creativecommons.org/licenses/by/4.0/). 